Int. J. Odontostomat.,

13(3):305-309, 2019.

\title{
Influence of Prolonged Tooth Bleaching on Enamel Mass Variation
}

\author{
Influencia del Blanqueo Dental Prolongado en la Variación de Masa del Esmalte Dental
}

\author{
Mara Eliane Soares Ribeiro1; Heitor Sales de Barros Santos'; Juliana Costa Pereira Baia²; Roberta Pimentel de \\ Oliveira; Mário Honorato da Silva e Souza Júnior ${ }^{3}$ \& Sandro Cordeiro Loretto ${ }^{4}$
}

RIBEIRO, M. E. S.; SANTOS, H. S. B.; BAIA, J. C. P.; OLIVEIRA, R. P.;SOUZA JÚNIOR, M. H. S. \& LORETTO, S. C. Influence of prolonged tooth bleaching on enamel mass variation. Int. J. Odontostomat., 13(3):305-309, 2019.

\begin{abstract}
The objective evaluate was the influence of prolonged tooth bleaching with $10 \%$ carbamide peroxide $(10 \mathrm{CP})$ on tooth enamel mass variation. Ten healthy bovine incisor teeth were divided $(n=5)$ into $\mathrm{G} 1$ - storage in distilled water and G2 - storage in artificial saliva. The samples were weighed in an electronic analytical balance at the following times: T0 - before application of the bleaching gel, T1 - after 14 days of bleaching (the time recommended by the manufacturer), T2 - after 21 days of bleaching (50\% increase in the time recommended by the manufacturer), and T3 - after 28 days of bleaching (100\% increase in the time recommended by the manufacturer). The data were subjected to ANOVA for related samples $(p=0.05)$. The highest mean was observed in $\mathrm{G} 2(0.5982 \mathrm{~g})$ and the lowest mean was observed in $\mathrm{G} 1(0.3074 \mathrm{~g})$ at T2 and T3, respectively. Significant differences were observed between the groups at all times. Overall, 10CP caused variation in the enamel mass after a $100 \%$ increase in the use time recommended by the manufacturer, with a decrease in mass when distilled water was used as the storage medium and an increase when artificial saliva was used.
\end{abstract}

KEY WORDS: tooth bleaching, tooth enamel, peroxide, in vitro.

\section{INTRODUCTION}

A growing demand for aesthetic interventions in the field of health exists, and this same trend is apparent in dentistry. The demand for a whiter and more harmonious smile is increasing, and tooth bleaching is among the most requested procedures (Carey, 2014).

Vital home bleaching is probably the most frequently used technique because it has certain advantages relative to the in-office technique, such as ease of application, low cost, safety and a high success rate (Sulieman, 2005). With this technique, a low concentration of bleaching agent is used, mainly 10 to $22 \%$ carbamide peroxide-based or 3.5 to $10 \%$ hydrogen peroxide-based agents. In general, use of $10 \%$ carbamide peroxide for $8 \mathrm{~h}$ daily or a concentration of $15-20 \%$ for $3-4 \mathrm{~h}$ daily is recommended for at least two weeks (Alqahtani, 2014).
The literature states that home tooth bleaching techniques are considered effective and safe when used under professional supervision. However, patients undergoing home treatment are active participants in their therapy because they are in possession of the bleaching gels and can use the bleaching product for a longer time than determined by a dentist to obtain a faster result, which may cause undesirable effects on dental structures (Abouassi et al., 2011; Niat et al., 2012).

The changes in the enamel caused by the use of peroxides for bleaching are closely related to the concentration of the bleaching gel and the exposure time because with increases in these values, oxidation will be more prolonged and intense, resulting in complications and more exacerbated effects (Bodanezi et al., 2011; Meireles et al., 2012).

\footnotetext{
${ }^{1}$ Graduated in Dentistry, Federal University of Pará, Belém - Pará, Brazil.

2 Post graduate student of the program in Dentistry, Federal University of Pará, Belém -Pará, Brazil.

${ }^{3} \mathrm{PhD}$ in Biomaterials, Dental Materials Laboratory of the Postgraduate Program in Dentistry, Federal University of Pará, Belém - Pará, Brazil.

${ }^{4}$ Doctor in Dentistry (dentistry), Dental Materials Laboratory of the Postgraduate Program in Dentistry, Federal University of Pará, Belém - Pará, Brazil.
} 
In previous studies, a decrease in the surface roughness of post-bleaching enamel was observed as indicated by the lower surface roughness of the peroxide-exposed substrate compared to that of the substrate that was not exposed to peroxides (FaraoniRomano et al., 2008; Cvikl et al., 2016). During bleaching therapy, the initially eroded enamel surface layer may be lost by solubilization, and a more uniform underlying layer is speculated to remain, thus accounting for the loss of enamel structure after use of bleaching agents (Attia et al., 2015).

Therefore, considering the lack of studies on the damage caused to tooth enamel under an excessive bleaching regimen when using the home technique, the purpose of this study is to evaluate the possible variation in enamel mass after prolonged bleaching.

\section{MATERIAL AND METHOD}

This study was approved by the Ethics Committee on the Use of Animals under no. 3382190117. Ten bovine incisor teeth of the species Bos taurus indicus (mean age of 24 months) obtained from animals slaughtered at a cooperative abattoir were obtained; the teeth were erupted in the oral cavity, with a healthy crown and complete root formation.

The teeth were initially immersed in $0.1 \%$ thymol solution for one week (A Fórmula, Belém, Pará, Brazil) for disinfection, followed by removal of adhered periodontal tissue and prophylaxis with pumice paste. The teeth were then analyzed under a stereoscopic microscope $(40 x)$ to evaluate the vestibular enamel surface of the middle coronal portion, and teeth with cracks on the enamel surface were discarded. Next, the teeth were stored in distilled water $\left(4^{\circ} \mathrm{C}\right)$, which was replaced weekly.

The tooth crowns were cross-sectioned twice. The first section was made at a distance of $15 \mathrm{~mm}$, measured with a digital caliper (DIN 862, Mitutoyo, São Paulo, São Paulo, Brazil), from the cemento-enamel junction and parallel to the incisal edge. The second section was made $5 \mathrm{~mm}$ from the cemento-enamel junction to obtain samples of the middle portion of the tooth crown, with a height of $10 \mathrm{~mm}$. Next, a longitudinal section in the mesiodistal direction allowed separation of the buccal and lingual portions of the crown. The lingual portions and root of each crown were discarded, and the buccal dentin layer was removed with the aid of truncated conical diamond burs \#4138 (KG Sorensen - Cotia, São Paulo, Brazil) at high speed and under constant cooling, leaving only the vestibular enamel.

Then, all the fragments were immersed in an ultrasonic bath with distilled water for 20 min. Each enamel fragment was individually embedded using condensation silicone in circular polyvinyl chloride (PVC) matrices measuring $20 \mathrm{~mm}$ in diameter to receive the bleaching treatment. The specimens were randomly divided into two groups $(n=5)$ according to the storage medium used, G1 - storage in distilled water and G2 - storage in artificial saliva.

The bleaching agent used was $10 \%$ Simple Whiteness (10CP) (FGM, Joinville, Brazil), which was applied daily for $4 \mathrm{~h}$ at a ratio of $0.1 \mathrm{ml}$ of bleaching gel to $0.05 \mathrm{ml}$ of artificial saliva (Table I) by dispensing the agent on acetate trays that remained in contact with the surface of the tooth fragment (Cavalli et al., 2001; Aguiar et al., 2017). During this period, the specimens were placed in a plastic container with water at the bottom to maintain the humidity at $100 \%$, and the container was placed in a biological chamber $\left(37^{\circ} \mathrm{C}\right)$.

After daily application of the bleaching gel, the specimens were washed with air/distilled water spray (1 min), which was applied at a distance of approximately $5 \mathrm{~cm}$ from the surface of the enamel exposed to the treatment. Weights were measured at 0 days (T0) (before bleaching gel application) and after 14 days (T1) (the time recommended by the manufacturer), 21 days (T2) (50\% increase in the time recommended by the manufacturer) and 28 days (T3) (100\% increase in the time recommended by the manufacturer) of bleaching. For the measurements, the specimens were dried in a Philco Titanium Travel drier (Philco - Joinville, Santa Catarina, Brazil) for two min, the time required for no further change in the mass of the specimens and weighed in an electronic analytical balance (Quimis-AS 210, Diadema, São Paulo, Brazil) with a precision of 0.0001 , which provides the weight in grams (Zimmer et al., 2015). The specimens were again placed in their respective containers with the refreshed storage medium (artificial saliva or distilled water) and were kept in a biological chamber $\left(37^{\circ} \mathrm{C}\right)$ for $24 \mathrm{~h}$ until the next application of the bleaching gel.

After confirming the normality of the data distribution (Shapiro-Wilk test), the data were submitted to ANOVA for related samples, adopting a level of significance of $5 \%$, using the BioEstat $\circledast$ software (Sociedade Civil Mamirauá). 
RIBEIRO, M. E. S.; SANTOS, H. S. B.; BAIA, J. C. P.; OLIVEIRA, R. P.;SOUZA JÚNIOR, M. H. S. \& LORETTO, S. C. Influence of prolonged tooth bleaching on enamel mass variation. Int. J. Odontostomat., 13(3):305-309, 2019.

Table I. Description of the materials used in the experiment, along with their trade names, manufacturers and composition (according to their respective manufacturers).

\begin{tabular}{|c|c|c|}
\hline Material & Manufacturer & Composition \\
\hline Whiteness Simple bleaching gel & $\begin{array}{l}\text { FGM Produtos } \\
\text { Odontológicos Ltda, } \\
\text { Joinville, Santa } \\
\text { Catarina, Brazil }\end{array}$ & $\begin{array}{l}10 \% \text { carbamide peroxide, Carbopol, potassium } \\
\text { hydroxide, sodium fluoride, glycerol and deionized } \\
\text { water. }\end{array}$ \\
\hline Artificial saliva & $\begin{array}{l}\text { A fórmula - Farmácia } \\
\text { de Manipulação, } \\
\text { Belém, Pará, Brazil }\end{array}$ & $\begin{array}{l}\text { Sodium bicarbonate } 2190 \mathrm{mg} \text {, potassium phosphate } \\
1270 \mathrm{mg} \text {, magnesium chloride } 125 \mathrm{mg} \text {, calcium chloride } \\
441 \mathrm{mg} \text {, potassium chloride } 820 \mathrm{mg} \text {, sodium fluoride } 4.5 \\
\mathrm{mg} \text {, nipazole } 100 \mathrm{mg} \text {, sorbitol } 24 \mathrm{mg} \text {, } \\
\text { carboxyme thylcellulose } 8 \mathrm{mg} \text {, and distilled water } 3000 \\
\mathrm{ml}(\mathrm{pH}=7) \text {. }\end{array}$ \\
\hline
\end{tabular}

\section{RESULTS}

The mean (and standard deviation) of the mass variation values are shown in Table II. The descriptive analysis of the data showed that the highest mean mass was observed in $\mathrm{G} 2(0.5982 \mathrm{~g})$ and the lowest mean mass was observed in $\mathrm{G} 1(0.3074 \mathrm{~g})$ at 21 and 28 days, respectively. After confirming the normality of the data by the Shapiro-Wilk test, ANOVA for related samples was used with a significance level of $5 \%$. Significant differences were observed in all intragroup comparisons at the different times (between T0 and T1, T0 and T2, T0 and T3, T1 and T2, T1 and T3, and T2 and T3) in both groups. In $\mathrm{G} 1$, a decrease in enamel mass from T0 $(0.3955 \mathrm{~g})$ to $\mathrm{T} 3(0.3074 \mathrm{~g})$ was observed. In $\mathrm{G} 2$, the mass increased until the end of the 21 st day of bleaching (T2) $(0.5982 \mathrm{~g})$. However, at T3, corresponding to a 100 $\%$ increase in the time recommended by the manufacturer, a mass reduction $(0.5540 \mathrm{~g})$ was observed.

\section{DISCUSSION}

Bleaching therapy using $10 \%$ carbamide peroxide caused variation in enamel mass in the different storage media as reflected by a decrease in mass from T0 to T3 in G1 (distilled water). A different pattern was observed in G2 (artificial saliva), where an increase in mass was observed at the end of excessive bleaching therapy, $\mathrm{T3}$ (28 days), compared to the mass at T0, before the application of $10 \mathrm{CP}$.
Some bleaching agents have a lower than ideal $\mathrm{pH}$, which can cause changes in the mineral content of the enamel, contributing to the formation of shallow depressions, increasing the porosity of the substrate, and thus promoting slight tissue erosion (Cavalli et al., 2010). These changes may be greater when the contact time between the bleaching agent and the tooth surface exceeds that recommended by the manufacturer (Chen et al., 2008; Engle et al., 2010). However, studies have shown that the addition of calcium or fluoride to the bleaching gel formulation can minimize enamel mineral loss (Pretty et al., 2005; Ren et al., 2009).

The 10CP formulation used in this study has two desensitizing/remineralizing agents, sodium fluoride and potassium ions, and a near-neutral $\mathrm{pH}$ to avoid decalcification of the enamel and dentin, where it acts together with saliva to promote remineralization, which may have contributed to the mass gain observed in the group stored in artificial saliva.

A study comparing the remineralizing capacity of several artificial saliva formulations (and distilled water as a control solution) in initial enamel erosive lesions found that all artificial saliva formulations analyzed showed a remineralizing effect on the tooth enamel, which was not observed when distilled water was used (lonta et al., 2014). Another investigation reported increased enamel micro-hardness after subjecting specimens to a home bleaching protocol

Table II. Differences in the mean (and standard deviation) mass variations in G1 and G2 in grams (g) of dental enamel at days $0,14,21$ and 28 . ANOVA for related samples, $p \leq 0.05$.

\begin{tabular}{|c|c|c|c|c|c|c|c|c|}
\hline & \multicolumn{3}{|c|}{ G1 - Water Storage medium } & \multicolumn{5}{|c|}{ G2 - Artificial saliva storage médium } \\
\hline & T0 & T1 & T2 & T3 & T0 & $\mathrm{T} 1$ & T2 & T3 \\
\hline Mean & $0.3955^{\mathrm{A}}$ & $0.4225 \mathrm{~B}$ & $0.3847^{C}$ & $0.3074^{\mathrm{D}}$ & $0.5374^{\mathrm{A}}$ & $0.5787^{B}$ & $0.5982^{C}$ & $0.5540^{\mathrm{D}}$ \\
\hline Standard Desviation & $( \pm) 0.015$ & $( \pm) 0.013$ & $( \pm) 0.018$ & (土) 0.007 & $( \pm) 0.005$ & $( \pm) 0.009$ & $( \pm) 0.007$ & ( \pm ) 0.0009 \\
\hline
\end{tabular}


for up to eight weeks, with the samples stored in human saliva between bleaching gel applications at clinically realistic intervals and associated the increased microhardness to human saliva (Polydorou et al., 2018). These results corroborate the findings of this study as $10 \mathrm{CP}$ alone, even with remineralizing agents in its formulation, may not have been able to prevent the decrease in enamel mass observed in $\mathrm{G} 1$, indicating that the presence of saliva is essential for incorporation of the remineralizing agents into the substrate.

Human saliva is composed of various electrolytes, such as sodium, potassium, calcium, magnesium, bicarbonate and phosphates, as well as immunoglobulins, proteins, enzymes and nitrogen products (Demarco et al., 2011). Calcium, phosphate and some proteins work together to exert an antisolubility effect and modulate the processes of tooth demineralization and remineralization, which are highly important for enamel integrity (Goo et al., 2004). Artificial saliva, such as that used in this study, should interact with the tooth substrate in a manner similar to natural saliva, which is a basic prerequisite of an artificial oral environment, such as in in vitro studies.

Notably, the mass variation observed in this study may not be clinically representative when considering the processes that lead to daily dental wear, such as tooth erosion, where the intake of acids regularly found in the diet and/or from the body itself can cause loss of dental hard tissue and therefore tooth mass changes. One study demonstrated that the amount of dental calcium lost after $12 \mathrm{~h}$ of bleaching treatment was similar to that lost in dental elements exposed to soft drinks or juice for a few min (Grobler et al., 2009).

Another study indicates that bleaching with carbamide peroxide does not increase enamel's susceptibility to acid erosion or demineralization as observed during caries formation (Cavalli et al., 2010). Daily intake of soft drinks has also been demonstrated to be potentially more harmful to hard dental tissues than periodic application of peroxide bleaching gels (Engle et al.). Most studies suggest that tooth bleaching with low concentrations of hydrogen peroxide or carbamide does not have significant deleterious effects on the surface morphology of enamel and dentin, microhardness, roughness or calcium loss (Abouassi et al.; Chen et al.; Cvikl et al.).

However, the scientific literature is scarce regarding the consequences of deleterious habits and/ or the use of abrasive toothpastes together with excessive use of peroxides on dental structures. Potentially, these processes together can intensify enamel loss and incite relevant clinical repercussions (Grobler et al.).

Therefore, more studies, especially in situ studies, are essential to measure possible damage to enamel exposed to excessive bleaching under the influence of tooth brushing and diet and to evaluate whether saliva and the desensitizers/remineralizers present in bleaching gels can prevent possible mass variations.

\section{CONCLUSION}

The results showed that artificial saliva combined with gels containing desensitizing/remineralizing agents was able to prevent possible deleterious effects on enamel weight caused by prolonged bleaching.

\section{ACKNOWLEDGEMENTS}

The authors are thankful to CAPES for encouraging this study. The authors deny any conflicts of Interest related to this study.

RIBEIRO, M. E. S.; SANTOS, H. S. B.; BAIA, J. C. P.; OLIVEIRA, R. P.;SOUZA JÚNIOR, M. H. S. \& LORETTO, S. C. Influencia del blanqueo dental prolongado en la variación del esmalte dental. Int. J. Odontostomat., 13(3):305309, 2019.

RESUMEN: El objetivo fue investigar la influencia del blanqueamiento dental prolongado con peróxido de carbamida al $10 \%$ (10CP) sobre la variación de masa del esmalte dental. Las muestras se dividieron en dos grupos: G1, diez dientes sanos de los incisivos bovinos $(n=5)$ en agua destilada, y G2, almacenamiento en saliva artificial. Las muestras se midieron en una escala analítica electrónica de precisión en los siguientes tiempos: T0-antes de la aplicación del gel blanqueador, T1-después de 14 días de blanqueo (el tiempo recomendado por el fabricante), T2-después de 21 días de blanqueo (aumento de $50 \%$ en el tiempo recomendado por el fabricante), y T3-después de 28 días de blanqueo (aumento de $100 \%$ en el tiempo recomendado por el fabricante). Los datos se presentaron al ANOVA para las muestras relacionadas $(P=0,5)$. La media más alta se observó en G2 (0,5982 g) y la media más baja se observó en G1 (0,3074 g) en T2 y T3, respectivamente. Se observa- 
ron diferencias significativas entre los grupos en todo momento. En general, la $10 \mathrm{CP}$ causó variación en la masa del esmalte después de un aumento de $100 \%$ en el tiempo de uso recomendado por el fabricante, con una disminución en la masa cuando el agua destilada se utilizó como medio de almacenamiento y aumentó cuando se usó saliva artificial.

PALABRAS CLAVE: blanqueo dental, esmalte dental, peróxidos, in vitro.

\section{REFERENCES}

Abouassi, T.; Wolkewitz, M. \& Hahn, P. Effect of carbamide peroxide and hydrogen peroxide on enamel surface: an in vitro study. Clin. Oral Investig., 15(5):673-80, 2011.

Aguiar, J. D.; Medeiros, I. S.; Souza Junior, M. H. S. E. \& Loretto, S. C. Influence of the extended use of desensitizing toothpastes on dentin bonding, microhardness and roughness. Braz. Dent. J., 28(3):346-53, 2017.

Alqahtani, M. Q. Tooth-bleaching procedures and their controversial effects: A literature review. Saudi Dent. J., 26(2):33-46, 2014.

Attia, M. L.; Cavalli, V.; do Espírito Santo, A. M.; Martin, A. A.; D’Arce, M. B.; Aguiar, F. H.; Lovadino, J. R; do Rego, M. A.; Cavalcanti, A. N. \& Liporoni, P. C. Effects of bleaching agents combined with regular and whitening toothpastes on surface roughness and mineral content of enamel. Photomed. Laser Surg., 33(7):378-83, 2015.

Bodanezi, A.; de Bittencourt, M. E.; Bodanezi, R. V.; Zottis, T.; Munhoz, E. A. \& Carlini, B. Jr. Surface modifications on aesthetically restored teeth following home bleaching with $16 \%$ peroxide carbamide. Eur. J. Dent., 5(2):157-62, 2011.

Carey, C. M. Tooth whitening: what we now know. J. Evid. Based Dent. Pract., 14 Suppl.:70-6, 2014.

Cavalli, V.; Reis, A. F.; Giannini, M. \& Ambrosano, G. M. The effect of elapsed time following bleaching on enamel bond strength of resin composite. Oper. Dent., 26(6):597-602, 2001.

Cavalli, V.; Rodrigues, L. K.; Paes-Leme, A. F.; Brancalion, M. L.; Arruda, M. A.; Berger, S. B. \& Giannini, M. Effects of bleaching agents containing fluoride and calcium on human enamel. Quintessence Int., 41(8):e157-65, 2010.

Chen, H. P.; Chang, C. H.; Liu, J. K.; Chuang, S. F. \& Yang, J. Y. Effect of fluoride containing bleaching agents on enamel surface properties. J. Dent., 36(9):718-25, 2008.

Cvikl, B.; Lussi, A.; Moritz, A. \& Flury, S. Enamel surface changes after exposure to bleaching gels containing carbamide peroxide or hydrogen peroxide. Oper. Dent., 41(1):E39-47, 2016.

Demarco, F. F.; Meireles, S. S, Sarmento, H. R.; Dantas, R. V.; Botero, T. \& Tarquinio, S. B. Erosion and abrasion on dental structures undergoing at-home bleaching. Clin. Cosmet. Investig. Dent., 18(3):45-52, 2011.

Engle, K.; Hara, A. T.; Matis, B.; Eckert, G. J. \& Zero, D. T. Erosion and abrasion of enamel and dentin associated with at-home bleaching: an in vitro study. J. Am. Dent. Assoc., 141(5):546-51, 2010.

Faraoni-Romano, J. J.; Da Silveira, A. G.; Turssi, C. P. \& Serra, M. C. Bleaching agents with varying concentrations of carbamide and/or hydrogen peroxides: effect on dental microhardness and roughness. J. Esthet. Restor. Dent., 20(6):395-402, 2008.

Goo, D. H.; Kwon, T. Y.; Nam, S. H.; Kim, H. J.; Kim, K. H. \& Kim, Y. $\mathrm{J}$. The efficiency of $10 \%$ carbamide peroxide gel on dental enamel. Dent. Mater. J., 23(4):522-7, 2004.
Grobler, S. R.; Majeed, A. \& Moola, M. H. Effect of various toothwhitening products on enamel microhardness. S. A. D. J., 64(10):474-9, 2009.

Ionta, F. Q.; Mendonça, F. L; de Oliveira, G. C.; de Alencar, C. R.; Honório, H. M.; Magalhães, A. C. \& Rios, D. In vitro assessment of artificial saliva formulations on initial enamel erosion remineralization. J. Dent., 42(2):175-9, 2014.

Meireles, S. S.; Fontes, S. T.; Coimbra, L. A.; Della Bona, Á. \& Demarco, F. F. Effectiveness of different carbamide peroxide concentrations used for tooth bleaching: an in vitro study. J. Appl. Oral Sci., 20(2):186-91, 2012.

Niat, A. B.; Yazdi, F. M. \& Koohestanian, N. Effects of drying agents on bond strength of etch-and-rinse adhesive systems to enamel immediately after bleaching. J. Adhes. Dent., 14(6):511-6, 2012.

Polydorou, O.; Scheitza, S.; Spraul, M.; Vach, K. \& Hellwig, E. The effect of long-term use of tooth bleaching products on the human enamel surface. Odontology, 106(1):64-72, 2018.

Pretty, I. A.; Edgar, W. M. \& Higham, S. M. The effect of bleaching on enamel susceptibility to acid erosion and demineralisation. Br. Dent. J., 198(5):285-90, 2005.

Ren, Y. F.; Amin, A. \& Malmstrom, H. Effects of tooth whitening and orange juice on surface properties of dental enamel. J. Dent., 37(6):424-31, 2009.

Sulieman, M. An overview of bleaching techniques: 2. Night Guard Vital Bleaching and non-vital bleaching. Dent. Update, 32(1):3940, 42-4, 46, 2005.

Zimmer, S.; Kirchner, G.; Bizhang, M. \& Benedix, M. Influence of various acidic beverages on tooth erosion. Evaluation by a new method. PLoS One, 10(6):e0129462, 2015.

Corresponding author:

Sandro Cordeiro Loretto

Associate Professor I

in Dentists of the Federal University of Pará

Av. Conselheiro Furtado, $n^{\circ} 2312$

Torre Oásis, apto. 401

Cremação, Belém - PA

CEP: $66.040-100$

BRAZIL

E-mail: sandroloretto@hotmail.com

Received: 20-10-2018

Accepted: 29-03-2019 